\title{
The Quest for Liberation in South Africa: Contending Visions and Civil Strife, Diaspora and Transition to an Emerging Democracy
}

\section{Ian Liebenberg}

\section{Introduction: Purpose of this contribution}

To write an inclusive history of liberation and transition to democracy in South Africa is almost impossible. To do so in the course of one paper is even more demanding, if not daunting. Not only does "the liberation struggle" in South Africa in its broadest sense span more than a century. It also saw the coming and going of movements, the merging and evolving of others and a series of principled and/or pragmatic pacts in the process.

The author is attempting here to provide a rather descriptive (and as far as possible, chronological) look at and rudimentary outline to the main organisational levels of liberation in South Africa since roughly the 1870's. I will draw on my own work in the field ${ }^{1}$ over the past fifteen years as well as other sources ${ }^{2}$. A wide variety of sources and personal experiences inform this contribution, even if they are not mentioned here. Also needless to say, one's own subjectivities may arise - even if an attempt is made towards intersubjectivity.

This article is an attempt to outline and describe the organisations (and where applicable personalities) in an inclusive and descriptive research approach in

See Liebenberg (1990), Ideologie in Konflik, Emmerentia: Taurus Uitgewers; Liebenberg \& Van der Merwe (1991), Die Wordingsgeskiedenis van Apartheid, Joernaal vir Eietydse Geskiedenis, vol 16(2): 1-24; Liebenberg (1994), Resistance by the SANNC and the ANC, 1912 - 1960, in Liebenberg et al (Eds.) The Long March: The Story of the Struggle for Liberation in South Africa. Pretoria: Kagiso-Haum Publishers; Liebenberg \& Lortan (1994), The role of the labour movement in the Struggle for Liberation, Ibid; Liebenberg (1996), The long haul to democracy: The Story of Constitutional Development and Transition in South Africa, Journal for Contemporary History, vol 21(2): 22-25; Liebenberg (1989), Responses to the ANC Constitutional Guidelines, Occasional Paper No 25. Mowbray: Idasa.

See source list. On this topic, the interested reader may benefit from a rather wide consultation of the sources provided here. 
what is termed "the struggle for liberation". This description by nature of South African politics, refers extensively to contending visions and ideologies, to various strategies for liberation and to the eventual transition from a minority state to an emerging democracy. Whereas other papers at this conference/chapters in this publication will refer to strategic and military aspects such as military history, historical military clashes, strategies and tactics, logistics and more contemporary issues such as force deployment and projection and peace operations, this chapter deals with socio-political history and the historical clash over power and scarce values that South Africa(ns) experienced during the $20^{\text {th }}$ century. It is about the politics of difference and unity. And it is about reflections on (a) historical clash(es) for power. Further it is about the quest for liberation and democracy in South Africa by the ANC and others before and after the ANC.

This contribution is not - and does not claim to be - a complete historical "audit" of the struggle for liberation in South Africa. The chapter may or may not refer to issues central to politics, such as clashes over access and control of scarce resources (a perpetual source of conflict in many societies); it may refer to the theoretical frameworks (call it paradigms or ideologies, if you choose) that underpin(ned) these clashes. It may touch on issues such as political economy (PE). It accepts the major role that the African National Congress (ANC) played - and still is playing - in the politics of liberation and its aftermath. However it is not meant to write a praise song to the ANC as the one and only organisation that played a role in the struggle for liberation.

This article is not impartial. My conception of what is entailed in liberation is guiding the argument. The result is that certain movements (most notably those that participated in apartheid structures) are excluded from this contribution. Yet, an effort was made to reflect on an inclusive history of liberation (and perhaps also its outcomes). This is done by not only looking at the main groupings such as the SANNC and the ANC but also at the others such as the PAC and the Black Consciousness Movement. Some minor ones, such as the Liberal Party (LP) and the Armed Resistance Movement (ARM), whose contributions to the struggle for liberation often bordered on the farcical - and were perhaps all the more heroic for that - are also dealt with.

This contribution is not about one movement, but about various movements following the stream or vision of political and economical liberation in South Africa. It is not a write-up ("market blurpie") for any specific party, movement, organisation or institution ${ }^{3}$. It aims at inclusiveness in description as far

This chapter cannot vaguely hope to describe the role of trade unions and labour activities over the past century. It refers in the passing to the ICU (1920's) the white Building Workers' Union (1940's), South African Congress of Trade Unions (SACTU), CUZA/AZACTU, NACTU, the independent trade unions and Cosatu. The roles of trade unions and workers organisations are a vast research field and are well described elsewhere. See chapters by Hirson (1994:51-64 and 65-71), Leggassick (1994:173-186), Liebenberg and Lortan 
as humanely possible in our context. Lastly, it does not deal extensively and definitely not exclusively with the "armed wings" of the various liberation movements. I believe that it will be sufficiently dealt with in the course of this conference and the research to follow.

\section{From territorial war to liberal participation}

A general historical overview of black resistance to white rule or white domination has to take cognisance of the fact that armed resistance and political opposition were at times separately applied, and at times complimentary to each other. In this aspect South Africans share similar characteristics with many other communities in their struggles for political and economical liberation and autonomy.

But there is a second issue that deserves attention. In the aftermath of white settlement clashes over scarce resources began in all seriousness - in this case, land, water and grazing fields. Later minerals and gold were added to these historical clashes that seemed to be territorial and were mostly violent in nature ${ }^{4}$.

Edward Roux recalls an interesting story about the 1818 "Kaffir War" in Eastern Cape. After Makana's (self chosen) surrender to British forces, one of his followers in discussion with the English commander, Colonel Willshire remarked:

"The war, British Chiefs, is an unjust one. You are striving to extirpate a people whom you forced to take up arms. When our fathers and the fathers of the Boers first settled in the Suurveld (west of the Fish River), they dwelt together in peace. The flocks grazed on the same hills, their herdsmen smoked together out of the same pipes; they were brothers ..."

The tribesman continued: "We quarrelled with Gaika about grass... no business of yours. You sent a commando... We wish for peace; we wish to rest in our huts; we wish to get milk for our children; our wives wish to till the land. But your troops cover the plains, and swarm in the thickets, where they cannot distinguish man from women and shoot all" (Roux, 1964:14-15). Needless to say that things did not stay the same. They worsened. Clashes of a territorial nature increased. The Brits intervened again and again with force. ${ }^{5}$

(1994:227-240), Ncube (1985) and Webster (1985). See also Steven Friedman's classic work Building Tomorrow Today as well as references to unions in Lodge (1987) and Roux (1964). Ncube's work remains relevant for further study, while contemporary issues of the SA Labour Bulletin (SALB) are worth consulting.

On gold and the gold rush, see Rosenthal (1970), Gold! Gold! Gold! The Johannesburg Gold Rush. The historian, Pakenham's Scramble for Africa, may be informative too.

5 If things do not stay the same, they change! (Confucian Proverb). One could, or choose not to, see the philosopher Heracleitos in this statement. The sceptic may remark: When things change, they change for the worse. The optimist may wish to say: When they change, that may be for the better. Was it Hofmeyer or Brand that said: "Alles sal regkom ..."(?) Kwai-Koo-Tsu is somewhat more phlegmatic in 
The last "wars of resistance" as Pampallis (1991:7) refers to them, took place in the 1800's. It was an age of imperialism. Resistance was subjugated with force (Pampallis, 1991:6). The so-called last 'Kaffir-War' ended in 1878 in the Eastern-Cape. By 1869 Lesotho was subjected to the British Crown after annexation. The Sotho people defeated in 1854 a British Force at Berea and the Orange Free State Boers in the Sotho-Boer War of 1858 (Pampallis, 1991:7). This, however, could not prevent annexation.

After 1879 the Zulu Kingdom was defeated and broken up into chiefdoms controlled and appointed by British Authorities - A classic divide and rule strategy facilitated by indirect leadership and patronage. (The social theorist, Mamood Mamdami, point out that from Uganda in the north to South Africa, indirect rule and patronage through the perversion of traditional leadership structures, took place.) Almost without exception, British imperialists used this strategy.

The Bapedi peoples were subjected by the Brits in 1877 and 1879 after keeping the Transvaal-Boers at bay in the 1852, 1867 and 1869 wars/skirmishes. After defeat by the Boers in 1898, Vendaland fell under British control following the Anglo-Boer War (Pampallis, 1991:12-13).

After these dates there were still isolated attempts by military resistance or armed struggle as reflected by the Mampuru rebellion in Transvaal (1881) and the Bambata rebellion in Natal (1906).

These were usually dealt with by the ruling regime with a short, sharp show of force. In Suidwes-Afrika (previously Duits-Wes, now Namibia) the Bondelswarts rebellion in 1922 reflected some of these last-and desperate attempts - to resist an enemy/intruder armed with vastly superior weaponry (Maxwell \& Smith, 1970:29; Naude, 1999). ${ }^{6}$

Mokgethi Motlhabi (1984:1) argues: "It had already become clear to Africans that a different strategy would have to be sought if they were to achieve

observing change. He argues: "Patience, the essential quality of a man ..." Add to this: "Those who are patient in the trivial things in life and control themselves, will one day have the same "mastery in great and important things". The martial art teacher, Han, quoted in Hyams, $(1982: 21,23)$ For the professional military person all the above holds value - or at least a drop of truth.

Duitswes became a mandate of South African following the Peace at Versailles after WWI. It became known as Suidwes, the proverbial "fifth province" of South Africa. After resistance against the German occupier, the Bondelswarts, a Hottentot (KhoiKhoi) tribe made peace in 1904 (Die Vrede van Kalkfontein). New taxes, inclusive of "dog tax" led to rebellion against the Union as new mandatory occupying force. Jacobus Christiaan and Abraham Morris led an ill-fated resistance against the South African Police Force and Defense Force Units. The South African Air Force, then newly constituted was used twice in 1922. Both operations focussed on quelling what could be termed "internal disturbances", namely the Mine Workers' Strike on the Witwatersrand and the Bondelswarts Rebellion in Southern Namibia. (See Maxwell \& Smith, 1970:29 and Naude (2000)). 
their goal (of political freedom) at all". "On the whole their wars had ended in defeat before the superior (military - my insertion) might of the Westerners. Thus by 1882 the first African political organisation was formed in the Transkei, Eastern Cape" (Motlhabi, 1985:1). However, smaller political organisations started somewhat earlier according to Odendaal and Edward Roux.

\section{Precursors to the South African Native National Congress}

In 1879 a predominantly black organisation with political objectives was founded. It was called the Native Educational Association (NEA), and it sought to improve black education and introduce social welfare for black people (Odendaal, 1984:7). Various problems were closely examined and black people were encouraged to become involved in the issues that directly affected them, such as the liquor laws, pass laws and education. Figuring prominently in these activities were, among others, E K Ntsikana, E Makiwane, W B Rubusana, J T Jabavu and William Gqoba. Although the NEA faced considerable criticism from whites, it could, according to Odendaal (1984:7), hardly be called radical: "On the contrary, whites were asked to address meetings and the tone of the leaders was marked by moderation."

The Imbumba Yama Nyama (IYN) succeeded the NEA in 1982. It was pre-eminently a political organisation and in the struggle for national rights, the need for black unity was emphasised (Odendaal, 1984:8). The organisation's strongest support was in the Eastern Cape, particularly in Port Elizabeth, Cradock, GraaffReinet and Colesberg. But the IYN did not last long. Odendaal also mentions the rise of two other black political organisations: the South African Native Association and the Tembu Association. These two organisations made the first real efforts to coordinate black action. At about the same time the Gcuwa Mutual Improvement Society came into being. Through these and other local organisations, as well as Jabavu's newspaper, Imvo Zabantsundu, black people aired their grievances about the pass laws, "location" regulations, liquor laws and maladministration in black courts (Odendaal 1984:12). A second black newspaper, Izwi Labantu, was founded and contributed to the strengthening of black unity. The ideological framework within which black people operated at this stage was still predominantly liberal (Roux, 1964:109).

In the Cape Colony black people had limited political rights, for example, a qualified right to vote, but in the Transvaal and the Orange Free State their position was quite different.

In the independent republics of the Transvaal and Orange Free State the constitutional stand was simple and straightforward. There was to be no equality between the Bantu and Boer, both in church and state. The 
extension of the franchise to the Bantu in these two Republics was a matter that could never be contemplated (Sebidi, 1986:8-9) ${ }^{7}$.

The wish to extend the (Cape) liberal tradition to these territories was the incentive behind much of the black politics of the time (Sebidi, 1986:9).

This commitment to extend the liberal political framework was also expressed in the Transvaal Native Congress (TNC), founded in 1905, and in the Orange Free State Native Congress. In Natal, too, attempts were made to broaden the (extremely limited) franchise regulations (Sebidi, 1986:9). Sebidi indicates that these and other organisations, such as the African Peoples' Organisation (1903), fought for the strengthening and extension of the liberal tradition. Against this background the Treaty of Vereeniging between Britain and the defeated republics was a "world shattering disillusionment to the Africans" (Sebidi, 1986:9). The reason for their dismay was simple: the treaty was the prelude to the formation of the Union of South Africa, and for blacks the formation of the Union would symbolise the start of their increasing political emasculation. The fear that the formation of the Union would thwart the political aspirations of blacks was not unjustified: the inclusion of the former ZAR and OFS could jeopardise or even make their enfranchisement impossible - a possibility against which Tengo Jabavu had already warned earlier (Walsche, 1978:5).

As regards the so-called "Coloured" population, there are indications that they had been involved in franchise and education campaigns since the turn of the century. However, the "Coloureds" adhered to the rules of play of the political system. Their actions were often planned together with black people (Lewis, 1987:41). The ideology, which was patently liberal in orientation, favoured an action-directed programme for the extension of the franchise to brown and black people on a nonracial basis. At this stage there was also strong agitation for a liberal political system (Lewis, 1987:42).

\section{The founding of the South African Native National Congress in 1912}

The first half of the twentieth century was characterised by the efforts of white politicians to solve the "Native question" (Gerhart, 1978:21) within the framework of a policy of segregation. At the same time blacks were working within the parameters of a liberal approach to achieve political rights. It is ironic that these two frameworks not only "missed" each other, but eventually also diametrically opposed each other.

André du Toit, however, points out that all "whites" in the Transvaal did not accept it out of hand. In the letters columns of De Volkstem of 1876 "Een Boer" pleaded that black people should be regarded as "friends and fellow citizens ("vrienden en medeburgers')", also that their rights should be "acknowledged and respected (erkend en eerbiedigd [moeten worden]". "Een Boer" further pleaded for a new policy ["een nieuw politiek']" based on conciliation. The object of this: to prove that we seriously desire to live with them in peace ["dat het ons ernst is met hen in vrede samen te leven']" (Die Suid-Afrikaan, Summer 1986:20-21). 
According to Roux (1964:74), "the history of South Africa ever since 1910 has been a process of the whittling down of native rights". One result of the establishment of the Union was "the birth of a movement to unite all politically minded Africans in a single national organisation” (Roux, 1964:74).

The South African Native National Congress (SANNC) came into being as a result of the South African Native Convention. The latter was convened in reaction to the National Convention, where whites opted for union, and the organisers hoped to influence opinion locally and abroad. The Native Convention expressed its objection to the discriminatory clauses in the proposed Union Act and also dispatched a delegation to Britain to protest against the exclusion of blacks from the National Convention, but in vain (Odendaal, 1984:289).

On 8 January 1912 the South African Native National Conference was founded in Bloemfontein. It was a moderate organisation, which pursued national unity, bargaining for equal rights for black people and for equal opportunities. The strategy was clearly nonviolent, even nonmilitant (Sebidi, 1986:10-11; Roux, 1964:110-111; Maylam, 1986:155). The period from 1910 to 1960 was "on the whole, marked by sometimes powerful, at other times intermittent and hesitant activities of the ANC" as the SANNC would later be called (Sebidi, 1986:12). Clearly, the ideology of the SANNC was still ver y much a liberal one.

\section{The era 1912 to 1960}

The SANNC immediately sent a deputation to London to dispute the 1913 landownership laws. The notorious "Land Acts" (1913) was meant to institutionalise reservation areas or "Bantustans" through legislation. These acts would result in black South Africans losing land in the dominium or union and restricting black people to their "native land" areas. (See Walker, 1928:580). In effect it amounted to land grabbing from already (partially) disenfranchised people, one may argue ... at the least these laws implied segregation without consultation, to take a more lenient historical look. But then again, the legislation formed the cornerstone of many more laws to come ... (While) the deputation gained little success hope did not fade. At the close of the war in 1919, another deputation was sent (once again with little success). They were told that:

... (the) British Government could not interfere in the internal affairs of the Union of South Africa. They were advised to return to South Africa and humbly submit the grievances of the black men to the union government (Roux, 1964:111).

Maylam (1986:155) points out that - next to its grievance about unequal access to scarce values - the SANNC had a clear policy for building black solidarity and gaining non-black support. By 1920 the SANNC, then also beginning to be known as the African National Congress (ANC), made clear its opposition to the 
principle of segregation ${ }^{8}$. This coincided with the intense debate on the so-called "Hertzog laws", which black people perceived as a hardening of political segregation.

In the following years the ANC gradually became less active in politics and the Industrial and Commercial Union (ICU) rose to prominence. The ICU was established in 1919 and achieved reasonable success with mass mobilisation under the leadership of Clement Kadalie and George Champion. This was partly due to the solidarity between the ICU and the Communist Party of South Africa (CPSA). The latter was founded in 1918. The second half of the twenties saw the ICU gradually weakened by infighting and internal inconsistencies (Maylam, 1986:158159). By 1930 the ICU was a thing of the past (Sebidi, 1986:12). Several black labour unions had come into being since 1927, but both the ANC and the ICU were relatively inactive. Various possible reasons can be advanced, such as the economic conditions of the thirties, and internal squabbling and discord. The leaders of the movements may even have been too bourgeois. But here Maylam cautions:

It can be argued that some forms of African opposition in these early days of the century took on the character that reflected the interests of a bourgeois leadership, while the more militant forms of activism were generally worker inspired. However, a rigid class-based analysis of opposition and resistance would be misleading (Maylam, 1986:161).

He also points out that there were attempts at bridging the class differences. The League of African Rights, which was founded in 1929, made one such attempt. Also, the efforts of radical leaders between the CPSA, the ICU and the ANC (Roux 1986:161) met with failure.

Ideologically, the period before, during and after the Second World War saw a closer interaction between the CPSA (later SACP), the ANC and other groups. Black labour organisations and the Communist Party forged closer links (Roux, 1964:207). The ideology, however, was neither exclusively liberal nor exclusively socialist. Maylam (1986:188) maintains that the acceptance of the Freedom Charter by the ANC was in fact delayed for a long time because it had to accommodate a broad ideological spectrum: "To some liberals the Charter looked like a socialist programme; for some Marxists the Charter represented the ideals of dangerous bourgeois concessions to multiracialism". This aspect will be discussed fully later on.

To summarise then, by 1941 the ANC, as the most influential agent within black opposition politics, explicitly spoke of franchise for all black people. the fundamental idea among the white political elite of South Africa during this period. Walker (1928:580) says: "It was useless simply to shut the door in the faces of the Bantu. If their entry into industry was to be checked, outlet was to be provided on the land, and the idea underlying (my italics) the Natives Land Act of 1913 had been territorial segregation." 
While its ultimate goal was franchise and equal rights for all Africans, as these rights apply to whites, its immediate goal was the removal of "special disabilities" - disabilities made possible by the many discriminatory laws of the country (Motlhabi, 1985:40, my italics).

The claim to full political rights and equal economic opportunities, however, had a liberal basis and militant action was to be frowned upon by the ANC leadership (Maylam, 1986:156-157). At this stage repressive measures on the part of the authorities were relatively few. Usually there was only a "short, sharp show of force" (Maylam, 1986). After 1940 the situation changed rapidly, as the liberal elements within the movement were increasingly being questioned by people/activists who favoured a more radical attitude.

\section{An extended ideology and a new strategy}

Not only was the black ideology broadened during 1942 to 1952 , but a search was also started for radically different alternatives. Gerhart (1947:48) asserts that

$\ldots$ the world of social and political ferment ... in 1943 was [a] very different [one] from [earlier]. It was a harsher world, one in which Africans with access to education were growing up with fewer illusions about the nature of white rule.

She continues:

A profound skepticism regarding white motives and the promises of "trusteeship" had set in, faith in the inevitability of enlightenment was dead, and a new mood of defiance and self-assertion was taking its place in setting standards of thought and behaviour among younger Africans.

This attitude was reflected in the new content with which the African National Congress Youth League (ANCYL) sought to infuse the black ideology. As early as 1943 the view was expressed that "freedom, democracy, Christianity and human decency could not be attained until all 'races' in South Africa participated therein" (Motlhabi, 1985:41).

The non-racial element within the framework now becomes clear. The Youth League added the following element to the existing paradigm:

The fundamental aims of this creed [African Nationalism] were to create a single entity out of heterogeneous groupings of Africans to free Africa as a whole and South Africa in particular from foreign domination and leadership; and to make it possible for Africa "to make her own contribution to human progress and happiness". The long-term goal of the ANCYL was "true democracy", which guaranteed minority rights in a democratic constitution. The immediate goal of its political action was "direct representation of Africans in parliament on a democratic basis". "Freedom in our Lifetime" was the League's motto (Motlhabi, 1985:41). 
Furthermore, this nationalism was defined in such broad terms that it was possible to include other groups and individuals (Motlhabi, 1985:42). By 1940 the ideology was quite extensive. All that was lacking was "its elaboration and the devising of a suitable strategy to accompany it". By 1940 revolutionary language was not yet commonly used. He refers, for instance, to the "creation of a society in South Africa based on the upholding of democratic values" without advocating a revolutionary overthrow of the minority regime (Motlhabi, 1985:42-43). Motlhabi labeled the political rhetoric of the time as "reformistic", thus orientated towards political reform rather than an overthrow of systems.

It was probably hoped that the white government would be able to accommodate the "reformist" black ideology in its point of view. That hope was dashed, however, as it became increasingly clear that whites - particularly the Afrikaners - were striving purposefully to attain an exclusive (Afrikaner) dominance of power (Gerhart, 1978:47).

When one considers the material interests involved in the struggle for access to scarce resources, the black ideologists probably expected too much. In any event, the onus would be on the ANCYL to heed this, to extend its ideological orientation accordingly, and to renew its strategy. A year after the national Party had come to power, the ANCYL decided on a programme of action. Noncollaboration with government institutions was among the strategies it advocated, and it recommended boycotts, strikes and civil disobedience as part of a strategy of resistance (Motlhabi, 1985:26). Luthuli (1962:98) shows that 1949 brought a "fundamental change of policy and method". Now the franchise was important, and deeds would have to replace words.

In the opinion of Luthuli (1962), the National Party's takeover of power and the implementation of a series of apartheid laws left no doubt that the programme of action had to be followed diligently. Accordingly, the years 1950 and 1951 were characterised by sporadic demonstrations. At that time a joint planning committee was also initiated by the ANC (Luthuli, 1962:99). For Luthuli this committee was an important step.

The very fact that it was able to be formed and to function was a sign that the white race in South Africa was beginning to think and act across barriers of race. The desire to shed apartheid could now at last be translated into outward expressions (Luthuli, 1962:99-100).

The committee was the forerunner of the Defiance Campaign of 1952, which was decided upon in 1951 at the National Conference of the ANC in Bloemfontein. Luthuli (1962:102-103) gives the following reasons why this campaign was preferred to other strategies:

Had Congress ever been an organisation which placed reliance on bloodshed and violence, things would have been simpler. What we have aimed to do in South Africa is to bring the white man to his senses and not to slaughter him. Our desire has been that he should co-operate with us, and we with him ... Congress has adapted itself to the real needs of the 
situation. And with each adaption we have brought ourselves and our country nearer to the vision of a homeland where man may eventually live at peace with neighbours of all races - because they are really neighbours, not white masters and other-race servants.

The ideological framework appears to have accommodated both a nonracial and a liberal attitude. There was also a rejection of the formation of classes and rigid class distinctions. The Communist Party, for instance, took a strong stand against this. Moreover, there was a definite aversion to violence as an instrument for change. All this led to a philosophy and praxis of peaceful, though active resistance.

\section{The Defiance Campaign}

In 1950 peaceful opposition on a large scale was still possible. In 1952 the Defiance Campaign would be launched as "a protest based on our claim for human dignity".

The target of the Campaign was unjust, oppressive laws. The intention was to disobey these laws, suffering arrest, assault and penalty if need be without violence (Luthhuli, 1962:105).

The campaign lasted about four months and involved a wide range of people. It started in Johannesburg and Port Elizabeth, but soon spread to the Eastern and Western Cape, Durban and Bloemfontein. More than 8000 people were arrested. The ANC leadership was apprehended under the Act on the Suppression of Communism, later brought to trial and given suspended sentences. The clampdown by the state made further organised resistance impossible and the Defiance Campaign stalled. Ultimately, the campaign's greatest value probably lay in its popularising the ANC. It was an era of peaceful resistance. Despite clear opposition, however, the era was also characterised by the implementation of further apartheid legislation, for example, the Bantu Education Act (1953) that was implemented by the National government despite public protests and a boycott action.

\section{The Congress Alliance and the reaction to it}

By 1953 the ANC's decision in principle to cooperate with other groups, was taken further. It already cooperated with the South African Indian Congress, but an alliance was also entered into with the South African Coloured Peoples' Organisation (SACPO) and the South African Congress of Democrats (COD) (Gerhart, 1978:105). This closer contact culminated in the preparations for and holding of the Kliptown Conference, or Congress of the People, where the Freedom Charter was adopted. Thereupon the Freedom Charter became the policy document of the organisation. Some historians maintain that the document was a declaration of comprehensive nationalism and that the manifesto deviates from the idea of "Africa for the Africans". For Luthuli the document was "line by line the direct outcome of conditions - harsh, oppressive and unjust conditions ... It attempted to 
give a flesh and blood meaning, in the South African setting, to such words as democracy, freedom, liberty."

The Freedom Charter left room for criticism and debate on its application and meaning - a debate that continues today (Cronin \& Suttner, 1986). Within a year of the Kliptown Conference, the ANC officially accepted the document. Ideologically, the charter was an attempt at reconciliation: it endeavoured to link liberal, nonracial capitalism with more socialist orientations (Maylam, 1986:188). This pragmatic choice left the charter open to wide interpretation, but it did have the advantage that, as a conciliatory document, it could mobilise support over a broad spectrum (Adam \& Moodley, 1986:95-96). The document did not represent a specific ideology because "its authors seem to have taken care to respond to a broad range of interests" (Lodge, 1983:73).

The Charter was seen as an ideologically inclusive document by many others. This brought its own problems. Hudson (1986:7) regarded it as "notoriously ambiguous". The clause on the economy, in particular, unleashed an ideological and semantic controversy. The Africanists dismissed the document as too inclusive and moreover, "foreign to African Nationalism" (Hudson, 1986:8). Some people see the Charter as anti-capitalist, but according to Hudson (1986:8,9,32-33), it does not necessarily rally the "people of the land" to a socialist praxis (although it could be interpreted as such). For Cronin and Suttner the Freedom Charter is "a document that seeks to win support of all those who oppose apartheid ... all classes and strata who have an interest in its destruction" (Hudson, 1986:9).

By 1987 the Freedom Charter was not regarded as a blueprint for socialism. Some saw in it a clear pointer to a mixed economy (Sibiya in Polley, 1988:63), whilst others accepted it more as a call to improved social welfare. In the words of Andrew Boraine (1987:6):

Thus while the Charter is not a socialist document it puts forward the democratic demand for an end to exclusive control of the South African economy by monopoly capital - both national and international.

The government reacted sharply to the formulation of the document. In 1956 the leaders of the Congress were arrested and a lengthy "treason trial" followed. However, the state could never prove that the group that issued the Kliptown Declaration, had envisaged a communist state. Shortly after the promulgation of the Prohibited Organisations Act, 1960 (Act 34 of 1960) the ANC and the PAC were declared illegal. However, such hard-hitting action did not succeed in bringing the resistance to an end. ${ }^{9}$

In 1950 the National Party Government passed the Suppression of Communism Act in terms of which the Communist Party was declared illegal. The act made provision for the governor-general to ban any organisation if it appeared to promote the objects of communism. The definition of communism was extremely broad. Horrel (1982:201) discusses this and other repressive legislation, for instance the Illegal Organisations Act (1960), the Affected Organisations Act (1974) and the Internal Security Act 
The Kliptown events did not elicit strong reaction from the white regime alone. Some Africanists - who since the forties had become an increasingly strong grouping under Lembede - also sharply criticised the Freedom Charter. Gerhart points out that the multiracial alliance and the document that ensued from it, failed to convince the Africanists. To them it was not only contrary to the idea of "building the nation" as they saw it, but - apart from a limited definition of nationalism - it was also based on an alliance with Europeans who would undermine the objective of freedom per se (Gerhart, 1978:157-159). "The multiracial nature of the Congress was (...) regarded as contrary to the objectives and interests of Black Nationalism." These conflicting ideological orientations rendered further cooperation between the Africanists and the groups within the Congress alliance impossible. However, the Freedom Charter remained a rallying document for the Congress Alliance(s) throughout the 1980 and even later. To an extent, it was subsumed, but not relegated, by the Harare Declaration and the Constitutional Guidelines issued by the ANC in 1988/89.

\section{The PAC - a new ideology?}

In 1959 the Pan-Africanist Congress (PAC) - sometimes also called the Pan-Africanist Congress of Azania - was formed by a group of Africanists opposed to the multiracialism of the ANC.

The Africanists understood South Africa to be a colonial country where the basic contradiction was racial and could only be resolved through racial conflict. Also, Africans naturally embraced ethnic nationalism which only had to be encouraged for the "masses to rise" in revolution (SACB, 1986:8)

The breach with the ANC occurred because it was perceived as deviating from its "original" tradition. The Africanist philosophy included brown people and some Indians in the term "African people". Certain groups, however, were excluded because of their opportunistic participation in the privileges that were provided by the existence of a white regime (Motlhabi, 1984:73) ${ }^{10}$.

The short-term objectives of the PAC, namely the abolition of the pass laws and the improvement of wages and working conditions, often coincided with

(Amendment No. 79 of 1976). He shows how the white and black ideologies came to be diametrically opposed: the one focusing on greater political participation and access to scarce goods, the other concerned with maintaining its exclusivity and sole control of scarce goods through increasingly repressive means.

10 A class analysis was sometimes necessary to determine who was opportunistic and who not. It created major problems because the Africanists had rejected communism and, together with it, a priority position for Marxist analyses. In Sow the Wind Neville Alexander tries to synthesise these two poles. He identifies unity on three levels: tactical unity or unity for the sake of achieving a goal, strategic unity and theoretical or radical unity. The latter was seen as a priority, but would be influenced by the others. Obviously these three areas do result in strategic tensions. 
those of the ANC. The long-term objectives, however, were seemingly in conflict with those of the ANC. In short, it amounted to a government of Africans, by Africans and for Africans, but with a broadening of the concept "African" to include "everybody who owes his loyalty only to Africa and accepts the democratic rule of an African majority" (Motlhabi, 1985:81) 11 . The philosophical underpinnings is perhaps well described by Robert Mangaliso Sobukwe himself at the PAC launch in 1959: "Here is a tree, rooted in African soil nourished with the waters from the rivers of Africa, come and sit under its shade and become with us, the leaves of the same branch and branches of the same tree" (Ntloedibe, 1995).

Sobukwe and others pointed out that such an approach should not be equated with exclusivity but that eventually there were no reasons "why in a free and democratic Africa, a predominantly black electorate should not return a white man to Parliament, for colour will count for nothing in a free Africa" (Motlhabi, $1985: 81)^{12}$. Cooperation with other organisations was accepted, provided they had no vested interests in the current regime (Motlhabi, 1985:103).

In his evaluation of the movement, Motlhabi (1985:103-105) finds that the PAC has consistently maintained its original points of view. However, this was possibly precisely the weakness of the PAC. For those in the ANC, on the contrary, the strength of the ANC lay in its ability to adapt its ideology continuously.

Among other things the value of the PAC lay in that "it has become the beginning of a new era in black political awareness and response". Although it cannot be seen as a forerunner of the Black Consciousness Movement, it did contain elements that would receive greater attention in the latter.

The banning of the ANC and PAC ushered in a period that was less successful for the PAC than for the ANC. The PAC could muster little support at home and abroad. Moreover, the organisation was torn apart by internal strife and leadership issues.

Mothlabi analyses the differences between the ANC and the Africanist Movement, as represented by the PAC. He also looks at the short and long-term strategies of the $\mathrm{PAC}$ and their most important consequences - for instance what effect they would have on the formulation of a new black ideology in a movement such as the Black Consciousness Movement. See chapter 3 of his The theory and practice of black resistance to apartheid.

There is an excellent source available on the earliest intellectual roots and definition of Pan-Africanism: I. Geiss's The Pan-African Movement. The early social and intellectual context in which Pan-Africanism came into being, was well as the contributions to it by intellectuals such as W.E.B. du Bois, B.T. Washington, H. Moody and G. Padmore, are fully discussed. There is also an outstanding source on the origin of the PAC in South Africa, written from a participant and Africanist perspective: N.N. Mahomo's The rise of the Pan-Africanist Congress of South Africa. Another illustrative source is Ntloedibe (1995). For more information on the PAC, the ANC (post-1960) and the UDF (founded in 1983) the reader is referred to the relevant sources for further consultation. 
After it was banned, the ANC also started functioning underground. A direct result of the banning was that the organisation became ideologically more radical. The armed struggle was accepted as a modus operandi and the ANC as political organisation started cooperating more closely with other banned organisations. The military wing of the ANC, Umkhonto we Sizwe, was established in cooperation with the South African Communist Party. In 1963, a large number of the ANC's leaders, including Nelson Mandela, were arrested. Most of them received long jail sentences. After this, the ANC regrouped abroad and, especially after the fall of the former Portuguese colonies of Angola and Mozambique, the organisation gained momentum. Lodge (1985:7) points out that the ANC recovered its "political supremacy and its success in re-establishing itself at the centre of gravity in black politics" by the mid-1980s. The support, however, did not increase at home alone.

High-level meetings between American, British and European political figures and the ANC during the 1980s also testified to increasing support abroad.

According to the then president of the ANC, the struggle for liberation was

... not merely a struggle against apartheid; it is a struggle for power, for full citizenship in a society where there is no discrimination. It [the Black opposition] can be defined as a mass movement of all anti-racists, all anticolonialists, and all opponents of related systems ... (Tambo, 1974:5).

Ever since the Lobatsi and Morogoro Conferences in 1962 and 1969 respectively, the ANC had, partly militarily, but notably politically, became a factor to reckon with. At the Kabwe Conference (1985) it was decided to intensify the "people's war" (Lodge, 1986:9). Palmberg (1982:273-4) indicates how the guerilla actions of the ANC increased subsequently. The ANC was not so much a military threat; the threat that it posed to the government was that, politically, it developed into a legitimate opposition to the regime. The visit of the Eminent Persons' Group (EPG) proved that internationally the ANC's stature had gown considerably by 1986/87. The published report of the EPG (1986:79-84) made it clear that the ANC ought to play a role in any process of political negotiation. Some observers even referred to it as a "government in exile" (although the ANC itself rejected this designation).

The ANC with its non-racial approach was however not the only ideological actor on the South African political stage when it was unbanned in 1990 by the besieged De Klerk regime.

\section{Smaller, but not so unimportant in the broader historical collage of liberation}

Various social movements and/or political organisations registered their vociferous, sometimes, militant resistance against apartheid and minority rule. Some of these struggles bordered on the farcical, but perhaps of that, were all the more heroic. Perhaps, more important - all of them reflected moral involvement against exclusion and oppression and action in favour of inclusion, justice and equality (in contrast to mere/abstract equity). I have alluded elsewhere to the 
Trotskyists and trade unions, the Marxist Workers' Tendency (MWT), the Christian Institute, IDASA and the trade unions in general. But there were more ...

It is simply impossible to deal with all of them. And to cover for my political wickets, let me say at the outset here, that the role of the churches, the role of other religions, the role of women and smaller institutions such as the Centre for Intergroup Studies (Abe Baily Institute), the Christian Institute and the early phases of the Institute for Democracy in South Africa (Idasa) can simply not be covered in the course of a single contribution. Some more to read can be found in Gouws and Kadalie (1994) in Liebenberg et al, Liebenberg (1990), Nel (1994), in Liebenberg et al (1994), Hope and Young (1981), Christie (1986), Mangena (1989), Grossberg (2000) and Women Marching into the $21^{\text {st }}$ Century (HSRC, 2000).

Nonetheless, I have chosen here to discuss two much smaller parties/groups that played a significant role. A role belied by the numbers of people involved, the duration of the organisations and the (non-) achievements of the said organisations. If their role was Quixotic, their moral stance was notable. Their role and impact in hard political terms were perhaps minimal, yet the moral stances reflected by them still speak today in an emerging constitutional democracy.

These organisations were the Armed Resistance Movement (1962-1965), the Liberal Party of South Africa (1953-1968) and the Black Consciousness Movement (BCM) in South Africa/Azania (1970-). Andries du Toit (1994) describes the National Committee for Liberation (NCL) or the African Resistance Movement's (ARM) as "fragile defiance". It existed for a short while, coming together as a leftwing, mostly white group after the Sharpville crises. It numbered more or less fifty people. It was composed mainly of middle-class South Africans. It had consensus on the destruction of Apartheid and with it the National Party government. They however "had no clear idea of how this was to be achieved" (Du Toit, 1994:96).

In its short, very active life it's story "touched the bizarre and paradoxical", Du Toit argues. "Eventually their programme of action extended ultimately, simply to the decision to defy the might of the (apartheid) state through acts of sabotage" (Du Toit, 1994:96). As an organisation it made about every mistake in the book for a would-be guerrilla army and militant resistance group. Little groundwork, little or no contacts with major political organisations such as the ANC and the PAC at the time. Long-term planning was minimal. They hoped that their acts of sabotage would spark of a mass uprising, but they had little interaction with (black) communities, townships ("lokasies") or any significant outside networks. Some ventured into describing them as "amateurish intellectuals, naïve, arrogant and egotistical, who played with fire and got their fingers burnt"13 (Du Toit,

Not all intellectuals or philosophers are naive as solders. The philosopher, Socrates, was known to be able to swing a sword (in his earlier life) and simultaneously being apt with thoughts, words and questions. In our own history there was a Field Marshall Jan Smuts who also could swing a sword, excel in equestrian skills while mastering 
1994:96). They had little, if any access to arms and weaponry suited to guerilla warfare - and even less knowledge about armed resistance or the theories underpinning such resistance. They had no rear base, even less reserves and no political linkage with sympathetic states outside South Africa.

While oppression and hence the state's security apparatus (inclusive of intelligence and security police) were becoming well honed and while even major movements at the time like the PAC and the ANC reclined in activities, they moved headlong into sabotage within a restricted area. The chosen area being the economically active most populated and urbanised part of the country, namely the Vaal Triangle and Johannesburg. Incidentally and understandably so, this economic hub of South Africa was also the most well monitored part of South Africa by the security forces prevailing. In a few months after some sabotaging of pylons and the infamous Harris bomb on Johannesburg station, they were rounded up thoroughly by the security police. A total act of folly, one might say ...

What then was ARM's value? Du Toit (1994) argues that "they had been a grouping who tried to make the basis of unity with their fellow South Africans, not ideological commitment or doctrinal correctness, but the simple fact of common citizenship. This is a challenge that South Africans will face again in the years to come", he added somewhat prophetically (Du Toit, 1994:103) ${ }^{14}$.

\section{The Liberal Party - Liberation of a real or a special type?}

In May 1968 the Liberal Party of South Africa came to an end in Caxton Hall, Durban. Following the Prevention of the Political Interference Bill, prohibiting non-racial political activities, the LP publicly declared itself to be joining the Political Cemetery in South Africa under the banner "that summed up the South

the art of intellect, thought and the oratory. In Russian culture the likes of Lermontov mastered poetry, prose, romance and warfare at the same time.

While the ARM-group was not anarchists per se, they did share an important sub-text with anarchism: Militant moral outrage against a state that a-morally directs people's lives without a thought to spare for human suffering and the consequences of statebuilding as a cause and end goal in itself.

James Joll in an insightful endnote on the role (and value?) of anarchism remarked: " Although terrorist actions may cause shock and distress, they are nevertheless a less effective way of challenging the values of existing society than the continuous critique (my italics) of our social goals and values offered by philosophical anarchists. (The latter being) "an activity which has the effect of making us think again about our political and economic presuppositions. (The) anarchists have consistently pointed out the danger of making the wrong kind of revolution.... It is by their ruthless and extreme assertion of an uncompromising set of believes (in collectivity and community and property sharing) that the anarchists have given an example and issued a challenge. Like all puritans, they have succeeded in making us just a little uneasy about the kind of life we led" (Joll, 1979:266). ARM did exactly this to apartheid as a life-style, ideology and value-system through acts of sabotage and "terror", farcical as it might have been. 
Africa of the 1960's in two words: 'Freedom Farewell', (Van der Westhuizen, 1984:81).

The Liberal Party (LP) "stemmed from the United Party's inability and unwillingness to actively challenge the stream of apartheid legislation" (Van der Westhuizen, 1994:83).

The LP was established following the activities of the Liberal Association and the Torch Commando (ex-servicemen from WWII) that challenged the National Party's endeavors to remove Coloured Voters from the common poll. Its establishment was met with cautious optimism and outright rejection.

However, without the blessing of major black organisations (the PAC and ANC), and met with skepticism from non-racial organisations such as the Congress of Democrats (COD) and the Communist Party, it slowly entered the arena of extraparliamentary protest politics. It remained peaceful in its defiance. It was an attempt at peaceful and militant liberal opposition - a contradictory act of riding a wild political tiger while pacifying the urge to violent resistance.

For this they received rejection from mainstream black liberation politics and outright ridicule and harassment from the authoritarian Christian-Nationalist government.

For some the LP's efforts had value: "The LP did have a capacity to bring people of diverse views together and to get them to work together. It (had) the potential to act as an agent for change". (Peter Brown quoted by Van der Westhuizen, 1994:92).

Eventually torn-apart by the strains caused by militant reaction to apartheid and growing authoritarianism and repression from the NP government it "chose to commit suicide" in public in 1968.

What was its value? Van der Westhuizen argues succinctly: "It was certainly the only real liberal party in the history of South Africa to have originated among whites". And; "They were willing to go further in the search for true freedom in South Africa than any other white-controlled party, with the exception of the Communist Party and the COD." (Van der Westhuizen, 1994:93). These statements by Van der Westhuizen has to be seen against the background of other "liberal" parties (the United Party (UP), the Progressive Federal Party (PFP) and the Democratic Party (DP) that chose to embrace capitalism as an exploitative economic system and a class-based society in no uncertain terms from 1970 onwards. Amidst increasing authoritarianism, the latter parties paid lip-service to liberalism, while filling their pockets through apartheid and tri-cameral regulated labour - a criticism that was made clear and apt by the Black Conscious Movement (BCM), SASO, AZAPO and the SACP - albeit from different angles against "the South African Liberal". Van der Westhuizen is probably very apt in his observation on the LP: "There was never again a white-controlled party that fought under the banner of true liberalism (equality rather than equity and freedom and brother/sisterhood - my 
addition) for the unconditional freedom of all South Africa's inhabitants." (italics, mine) (Van der Westhuizen, 1994:93) $)^{15}$

\section{The Black Consciousness Movement (BCM): A moral stance against racism}

During the nineteen seventies black consciousness also made its appearance. As with Pan-Africanism, it held the view that liberation could be attained only through the "black experience". During the late sixties the South African Students' Organisation (SASO) broke away from white-controlled movements such as the National Union of South African Students (NUSAS). From the black consciousness point of view, liberation was a comprehensive concept that covered existential, political and economic liberation. It was moreover driven by a personal, unique experience of suppression. Violence as a means of liberation was rejected (Leatt et al., 1986:112). BC supporters strongly rejected liberalism, as did the ruling National Party and the Christian National ideologues. Partly as a result of this approach, the government of the day initially tolerated the BCM. "At first SASO and Black People's Convention (BPC) were taken to represent black expressions of the government's separate development policy, and were tolerated and perhaps encouraged" (Leatt et al., 1986:112). However, after 1976 and Soweto, the attitude of the government changed very quickly.

SASO and groups such as the Azanian People's Organisation (AZAPO) increasingly asked more incisive questions, and this more radical approach in turn resulted in tougher measures by the government (Leatt et al., 1986:114). In 1977 SASO was banned. Black consciousness and militant black-orientated groups persisted after the 1977 banning and contributed to the ongoing struggle for liberation. In the 1980's when "reform" (read: sham reform) under PW Botha was launched and corollary to this repression escalated, BC debates continue to play their role in the liberation discourse.

When the National Forum (NF) came into being in 1983, it consisted of more than 170 organisations. These included labour movements with black

Van der Westhuizen points out in this chapter in Liebenberg et al (1994) that LP members defected to the left (Communist Party, COD, and ANC) and to the right (United Party, the Republican Party, Progressive (Federal) Party, National Party, etc). He acknowledges the role of some committed liberals and people committed to individual freedom and the right to free association regardless of the government's policy, such as Van Zyl Slabbert, the late Tian van der Merwe, Jan van Eck, Pierre Cronjé, Molly Blackburn, Di Bishop and perhaps "even Helen Suzman" (Van der Westhuizen, 1994:93). But for him real liberalism was buried with the LP in 1968 in Durban. Given the close economic consensus between "liberals" and apartheid ideologues then, and "liberals" and GEAR protagonists now, he is probably correct in his observations. It is indeed no surprise that serious differences are developing between the pro- and anti-capitalist groups in South Africa. Given our history, it is also unlikely that these differences be accepted without resistance by those feeling that the GEAR programme has become a neo-liberal/neo-conservative philosophy and policy pushed by the ruling political and economic elite in cohort with the liberal/conservative opposition. 
consciousness leanings. For black consciousness adherents it was a reaction to the so-called new dispensation. The national forum also adopted the manifesto of the Azanian People.

[It was] a socialist document based on four principles: anti-racism, antiimperialism; non-collaboration with the oppressor and his political instruments, working-class organisations; and opposition to all ruling-class parties (Leatt et al., 1986:115).

Ideologically, there was a class approach that was rooted in the black worker's experience of suppression (Leatt et al., 1986:115). Alexander (1986:8485) summarised it as follows:

The positive historical task of Black workers in solving the national question in South Africa is the construction of the (socialist) nation of Azania. This construction takes place in all the dimensions of the social formation, i.e. economically, politically, and ideologically (my italics).

In August 1983 the non-racial United Democratic Front (UDF) was founded in reaction to the "new dispensation". The UDF was based on a non-racial ideology and strove for a new South Africa on the basis of one person, one vote (Boesak, 1984:175-176). It consisted of more than 400 affiliated organisations and represented a wide political spectrum. Unlike the national forum, the UDF was, therefore, far more confined to the non-racial ideological framework on the ANC.

By the mid-eighties there were two broad ideological movements, both with internal and external wings. One was the ANC, including other non-racial and more populist movements such as the UDF; the others were the PAC and the National Forum (later also the Pan-Africanist Movement). Although the latter two groups shared a common opponent in apartheid, there were also differences, and according to Leatt et al. (1986:115) these ideological differences had their origin in the ANC/PAC rift. Sebidi (1986:13) also refers to the differences - especially regarding the Freedom Charter and "multiracial strategies". He too maintains that these differences could be traced back to the break between the ANC and the PAC. For him black consciousness is a more sophisticated approach to the struggle for freedom: he calls it "an attitude of mind, a way of life". Sebidi (1986:13) warns that it might be too early to say whether there would be two divergent ideologies in the long term: "[It] remain to be seen whether it was a shift at the level of principles [i.e. ideology] or merely the level of strategies and tactics."

In my own interpretation the ideological split of these years was more related to a deep distrust (even hate) for liberalism, an ideology that paid lip service to "reform", while actively increasing economic exploitation of poorer people regardless of race. Hence it can be argued that South Africans are not set for a decrease in ideological differences post-1994/1996. On the contrary, as the current government veers to the right by means of its macro-economic ideology (GEAR) and placating liberal capitalism from the North Americas, resistance to the immediate and longer-term effects of such policies will increase in South Africa. 
In conclusion, then, through the years (black) opposition politics has gradually shifted from a liberal to a radical ideological orientation. It was the result of unsuccessful efforts from the second half of the nineteenth century to the 1950 s to obtain access to scarce political and economic goods in South Africa through liberal and moderate political participation (for instance in the Native Advisory Council). The forties and fifties brought a further shift: the demands broadened and the strategies became more militant, for instance in the Defiance Campaign. In the mid forties the debate on Africanism caused a rift in the already shifting ideology, which was brought to a head by the ANC's acceptance of the Freedom Charter and its participation in the Congress of the People. In 1959 the PAC was established. Henceforth, black politics was characterised by two distinctive ideological orientations, each with its own philosophy of resistance to the structures of apartheid. On the one hand there was the radicalised ANC with its ideology of nonracialism and its commitment to the armed struggle. This, however, should not be seen as a chosen via absolutis, but as a means to a political solution (Phillips, 1988:49). The ANC and other non-racial groupings such as the United Democratic Front, propagated a mixed economy and were in favour of a political system of "one person, one vote" in a unitary state (Boraine, 1987:6).

By contrast, there were the Africanist and black consciousness-oriented groups such as the PAC, AZAPO/AZANYU, AZAZM, the Unity Movement, the National Forum and the Pan-Africanist Movement. In his rejection of a liberal, nonracial approach - which for the black consciousness groups ultimately was merely a salve for the liberal conscience - Biko said:

It never occurred to the liberals that the integration they insisted upon was impossible to achieve ... One has to overhaul the whole system in South Africa before hoping to get black and white walking hand in hand to oppose a common enemy (quoted in Stubbs, 1978:78).

Biko also strongly rejected political involvement on the grounds of a sense of guilt and asked for motivated and committed participation, in other words "commitment" to comprehensive liberation from suppression (Stubbs, 1987:79-80). After "the struggle", that is after the conclusion of the strategy referred to, the Africanists would have been prepared to accept an inclusive nationalism (Alexander, 1985:47-48). The economic ideology of the groups mentioned leans towards Africa and/or workers' socialism. In both the nonracial and more black consciousnessoriented groups, there are those who were banned in the sixties, namely the ANC and the PAC. There are also groups in both categories that still adhere to and promote their ideologies on a nonviolent basis even after the 1994 founding elections. Each had their own modus operandi in the struggle against apartheid and the minority government before 1994.

The reaction against apartheid and white minority government set a process of increasing suppression in motion. Legislation banning organisations, security laws, government action against activists and increasing militarisation were proof of this. In 1984 a more or less permanent state of emergency was imposed. 
At the beginning of the sixties the exclusive white ideology started consolidating and entrenching itself through repressive measures. At the same time there were radicalised black ideologies and the efforts at resistance they generated. This ushered in the period of crisis for apartheid. In the eighties the government had to try to resolve the crisis by means of "new dispensation" and the "state of emergency" (Liebenberg, 1990). An era of almost totalitarian repression and a (white) political schizophrenia dawned. In a unilateral effort to retain power, the two-pronged strategy of "total onslaught" and "reform" was initiated. Throughout the eighties, South Africans were exposed to this ambiguous mechanism of reform and repression simultaneously.

By 1990, following the ascendancy of F.W. de Klerk to the presidency, the government - after more than forty years of minority government, and under increasing foreign and internal pressure - reluctantly begin paving the way for transformation through negotiation by unbanning the ANC and other banned groups.

Following an era of hard bargaining and transition-through-negotiation $(1990$ - 1993) the interim constitution was accepted in 1993. The first democratic elections (some refer to it as founding elections) took place in 1994. In 1996 South Africa become a constitutional democracy when the new Constitution (Act 108 of 1996) was passed by the South African parliament.

To build a democratic culture, to foster tolerance and economic growth and to enhance the process of democracy and human rights without reverting to authoritarianism, became our legacy through transition. The responsibility to maintain and extend this inheritance simultaneously to all South Africans regardless of their backgrounds became the joint imperative of our citizenry and political leadership.

\section{Appendix: A chronology of struggle and transition}

An inclusive history of liberation? Chronology of civil strife, liberation-politics and democratisation in South Africa, 1818 - 2000.

$1818-1879$ Last of the "native" wars of resistance against colonial expansion, Boer Republicanism, British Imperialism and colonization in Southern Africa. Zulu domination fought off by various tribes at great costs.

1870's Beginnings of black political organisations: resistance to pass-laws, land occupation by colonialists, trekboere and hut taxes.

1898 - 1901 Anglo Boer War / South African War. Boer Republics fought British Imperialism. "From Boer against Brit to Land of Boer and Brit", taking root, through the phenomenon of a modern resource war. 
1902 onwards

1906

1910

1912

1913

$1913 / 1914$

1914

$1914-1918$

$1920-1930$

1933

1940's - 1950's National Party takes power (1948) and successive apartheid laws implemented.

ANC active; Defiance Campaign (1955); Freedom Charter; PAC brake away developing. 
1950's - 1960's Banning and oppression of liberation movements. First rumblings of "the armed struggle" ("Armed propaganda"). PAC established 1959 and banned together with the ANC, SACP and SACTU.

1970's

$1972 / 73$

Total Onslaught ideology develops under P W Botha and Magnus Malan. Militarisation of the South African economy and white society triggered.

1976

Oil Price hikes internationally; widespread strikes amongst workers in Natal. Black Consciousness debates slowly introduced. National Security Management System being developed by the racist regime in Pretoria.

Soweto Rebellion. SADF entered Angola to prevent a "Marxist take-over" after the fall of colonial Portuguese control.

1977

Bantu Biko died in detention after torture. Banning of newspapers like The World and organisations like the Christian Institute. Broederbond advisors to B J Vorster suggest Three Parliaments ("White", "Coloured" and "Indian" with the explicit exclusion of black people.)

South Africa involved in pre-emptive strikes in "communist" states. These mainly aimed against SWAPO/ANC supporting Frontline Countries. Resistance building up against apartheid; Rising influence of securocrats in South Africa; further the militarisation of state, white society and the economy in South Africa.

Resistance grows; Tri-cameral parliament implemented after 'whites only' referendum. The "one million signatures campaign" against the Tri-cameral parliament; SADF involved in regional destabilisation as policy instrument of $\mathrm{P}$ W Botha, the State Security Council (SSC) and the National Party elite. Broederbond advisors to Botha play a crucial role in devising the exclusive and racially segregated Tri-cameral Parliament.

1983

United Democratic Front (UDF) and National Forum (NF) established.

"Reform" (Shamreform). At the time some Broederbonders worked closely with Military Intelligence and the Sensuurraad (Cencorship Board) on various Afrikaans University campuses. 
Eminent Persons Group (EPG), a Commonwealth Delegation, failed to negotiate a way out of continuing civil strife; attacks by SA on Lesotho, Mozambique (Maputo), Harare and Lusaka. Civil Strife continues, followed by mass-detentions. First meetings with the ANC by South African citizens against NP wishes. The international isolation of the Pretoria regime, a central pillar of ANC struggle continues; the disinvestment campaign picks up speed (Bishop Desmond Tutu and the South African Council of Churches (SACC) maintain that it is one of the only relative peaceful strategies to put pressure on the Pretoriaregime).

Meetings between South African democrats and the ANC continued; open defiance or second track diplomacy? The "Armed Struggle" now aimed at escalation. "Civilian targets" (so-called soft targets) become a debate.

Consequences of the Rubicon-speech by $\mathrm{P}$ W Botha felt through increasing sanctions. Civil strife continues. The break-away "Independent Movement" in white politics led by Dennis Worral, Esther Lategan and others contest NP strategy of "Security First" in April elections; the leader of the white opposition party in parliament (PFP) resigned from parliament calling Tri-cameralism a "farce" and an attempt at "sham" reform. He objects to the role of the State Security Council (Staatsveiligheidsraad); Institute for Democracy in South Africa (Idasa) established. Gen. Magnus Malan refers to IDASA as part "of a total intellectual onslaught " on South Africa. P W Botha and Magnus publicly declare the ANC as "enemy No. 1" of the South African State. First major meeting between an Afrikaans-speaking group with the banned ANC in Dakar, Senegal against the wishes of the NP.

Second and Third Track diplomacy by some continues (i.e. H W van der Merwe at the Centre for Intergroup Studies). International sanctions impact continues to be felt. South Africa seen as a pariah state by some. South Africa's involvement in the Frontline States problematised; the Battle of Cuito Canavale, (Angola). "Talks about talks" begin. Withdrawal of South African occupiers from Namibia started taking place. Some political prisoners inside South Africa released. 
1990

1990 's

1996

1998

1999

2000
Unbanning of liberation movements amidst growing national and international pressures on the National Party government.

Rolling mass action by the Mass Democratic Movement (MDM). PAC military activities stepped up. "Negotiation about negotiation" begins. Transitionthrough-negotiation starts: Logjam and progress. Transitional Executive Council (TEC); integration of armed forces (statutory and non-statutory forces) started; "founding elections" after World Trade Centre negotiations; Interim constitution and transitional arrangements implemented; President Mandela ("Madiba") inaugurated.

Act No 108 of 1996 and the Bill of Rights passed. South Africa now a constitutional state.

ANC increases support (66\% in votes, just some seats short of 66\% in Parliament after 1999 elections). Madiba retires.

South Africa and Botswana on request of SADEC invade Lesotho in a peace-operation to quell civil disturbances and to secure South African water supplies from the Lesotho Highlands Project.

Progress with the implementation of the constitution. First Report on progress published by the Technical Committee of Parliament.

The Reconstruction and Development Program (RDP) jettisoned in favour of macro-economic adjustment programme (GEAR); African Renaissance discourse revitalised under leadership of Pres. Mbeki; People against Gangsterism and Drugs (PAGAD) became militantly active in Western Cape. The Parliamentary opposition refers to untenable crime situation in South Africa.

Contending visions of democracy debated; Worldwide oil price hikes; Resistance against the IMF and World Bank in Seattle, Prague and elsewhere; Land invasions in Zimbabwe and Brasilia. Looming Government and organised labour split in South Africa. Privatisation to be sped up (announcement by Minister Jeff Radebe); The governor of the Reserve Bank, Mr Tito Mboweni, warns that confidence and perceptions in SA economy is important and urge politicians to avoid statements that are damaging to the economy; "Political re-alignment/restructuring on the 
cards?" debate in newspapers. Government especially criticized by workers organizations and the left.

Mr Steve Tswete declares PAGAD as "Enemy No. 1" of the South African government. The "Racism in the Media Report" appears amidst controversy. Newspapers (critical of government policy) are branded as racist and subversive towards democracy. In September 2000 the Rand dropped to an unprecedented low against the American Dollar. The ruling party initially refuses to announce local government election dates.

First anti-globalisation demonstrations taking place in some city centers in South Africa.

No easy answers in a democracy ...

2001

?

\section{Sources}

Alexander, N. 1985. Sow the Wind: Contemporary Speeches, Johannesburg: Skotaville Publishers.

Alexander, N. 1986. "Approaches to the National Question in South Africa, in Transformation 1(1): 63-95.

Boesak, A.A. 1977. Farewell to Innocence: a Socio-Ethical Study on Black Theology and Black Power. New York: Orbis Books.

Christie, P. 1986. The Right to Learn: The Struggle for Education in South Africa. Johannesburg: Ravan Press.

Commonwealth Report. 1986. Mission to South Africa: The Findings of the Commonwealth Eminent Persons Group on Southern Africa. Middlesex: Penguin Books.

Geis, I. 1968. The Pan African Movement. Londen: Methuen Publishers.

Gerhart, G.M. 1978. Black Power in South Africa: The Evolution of an Ideology. Los Angeles: University of California Press.

Grossberg, A. (Ed.) 2000. Wathint' abafazi, wathint' imbokodo: Women Marching into the $21^{\text {st }}$ Century. Report compiled on request from DACST. Pretoria: HSRC.

Hope, M. \& J. Young, 1981. The South African Churches in a Revolutionary Situation. New York: Orbis Books. 
Human Sciences Research Council. 2000. Women Marching into the $21^{\text {st }}$ Century. Pretoria: HSRC Press.

Hyams, J. 1982. Zen in the Martial Arts. Sydney: Bantam Books.

Legassick, M. 1985. "South Africa in a Crises: What Route to Democracy?" African Affairs 84(337): 587-603.

Lewis, G. 1987. Between the Wire and the Wall: A History of South African 'Coloured' Politics. Cape Town: David Philip.

Liebenberg, I, et al. (Eds.). 1994. The Long March: The Story of the Struggle for Liberation in South Africa. Pretoria: Kagiso-Haum Publishers.

Liebenberg, I. 1990. Ideologie in Konflik. Emmerentia: Taurus Uitgewers.

Lodge, T. 1983. Black Politics in South Africa since 1945. Johannesburg: Ravan Press.

Luthuli, A. (1962) 1982. Let My People Go: An Autobiography. Glasgow: Fount Paperbacks.

MacShane, D., M. Plaut et al. 1984. Power! Black Workers, their Unions and the Struggle for Freedom in South Africa. Nottingham: Spokesman Books.

Mahomo, N.N. 1968. The Rise of the an Africanist Congress of South Africa, unpublished M.A.- dissertation, Massachussets Institute of Technology, Massachusetts.

Maylam, P. 1986. A History of the African People of South Africa: From the Early Iron Age to the 1970s. Cape Town: David Philip Publishers.

Mosala, I.J. \& B. Thagale. (Eds.) 1986. The Unquestionable Right to be Free: Essays in Black Theology. Johannesburg: Skotaville Publishers.

Motlhabi, M. 1985. The Theory and Practice of Black Resistance to Apartheid: A Socio-ethical Analysis. Johannesburg: Skotaville Publishers.

Mzala, C. 1988. Latest Opportunism and the Theory of the South African Revolution: a Critique of an Ideological Trend against the Freedom Charter. Lusaka (Publishers unknown).

Ncube, D. 1985. The Influence of Apartheid and Capitalism on the Development of Black Trade Unions in South Africa. Johannesburg: Skotaville Publishers.

Nel, F.B.O. 1989. Die stryd om mens te wees ... die storie van swart teologie in Suid-Afrika, Ongepubliseerde M.Th.-skripsie, Universiteit van WesKaapland (UWK), Bellville.

Odendaal, A. 1984. Vukani Bantu! The Beginnings of Black Protest Politics in South Africa to 1912. Cape Town: David Philip.

Palmberg, M. 1983. The Struggle for Africa. Londen: Zed Press. 
Pampallis, J. 1991. Foundations of the New South Africa. Cape Town: Maskew Millar Longman.

Polley, J. (red) 1988. The Freedom Charter and the Future. Mowbray: IDASA.

Rosenthal, E. 1970. Gold! Gold! Gold! The Johannesburg Gold Rush. Johannesburg: AD Donker Publisher.

Roux, E. 1964. Time longer than rope. Madison: The University of Wisconsin Press.

Saunders, C. 1988. The Making of the South African Past: Major Historians on Race and Class. Cape Town: David Philip Publishers.

Sebidi, L. 1986. "The Dynamics of the Black Struggle and its Implications for Black Theology", in Mosala \& Thlagale (reds.), The Unquestionable Right to be Free: Essays in Black Theology.

Stubbs, A.C.R. 1988. Steve Biko: I write what I like. London: Penguin Books.

Tambo, O.R. 1974. "The Black Reaction”, Issue 4(3): 3-5.

Turner, R. 1972. The Eye of the Needle: Towards Participatory Democracy in South Africa. New York: Orbis Books.

Webster, E. 1985. Cast in a Racial Mould: Labour Process and Trade Unionism in the Foundries. Johannesburg: Ravan Press.

\section{Suggested Reading}

Butlitsky, A. 1973. "Knot of Apartheid Contradictions", International Affairs (Moscow), no. 2: 80-86.

Catholic Institute for International Relations (CIIR). 1988. Now Everyone is Afraid: The Changing Face of Policing in South Africa. Elsiesrivier (Publisher unknown).

Davenport, T.R.H. no date. "The 1913 Land Act”, Sash-Magazine 26(2): pages unclear.

Davenport, T.R.H. 1977. South Africa: A Modern History. Braamfontein: Macmillan Publishers.

Davis, S.M. 1987. Apartheid's Rebels: Inside South Africa's Hidden War. New Haven: Yale University Press.

Erwin, A. \& E. Webster, "Ideology and Capitalism in South Africa", in Schlemmer, L. \& E. Webster (Eds.) Change, Reform and Economic Growth in South Africa. Johannesburg: Ravan Press. 
Forman, L. 1959. Chapters in the history of the march to freedom. Cape Town (a New Age Pamphlet).

Frankel, P.H. 1980. "South Africa: The Politics of Police Control”, Comparative Politics 12(4): 481-499.

Frankel, P.H. 1984. Pretoria's Praetorians: Civil-Military Relations in South Africa. Cambridge: Cambridge University Press.

Frankel, P.H., N. Pines et al. 1988. State, Resistance and Change in South Africa. Johannesburg: Southern Books.

Friedman, S. 1987. "The Struggle within the Struggle: South Africa Resistance Strategies", in Transformation, vol. 3.

Hamilton, G. \& G. Maré. 1987. An Appetite for Power: Buthelezi's Inkatha and the Politics of 'Loyal Resistance'. Johannesburg: Ravan Press.

Hirson, B. (1994). The Trotskyist Groups in South Africa, 1932-1948. In: Liebenberg, I et al: $52-65$.

Hirson, B. (1994). The Trotskyists and the Trade Unions. In: Liebenberg, I et al: 65 -72 .

Horrel, M. 1982. Race Regulations as Regulated by Law in South Africa, 1948 1979. Pietermaritzburg: Natal Witness Press.

Houston, G. 1999. The National Liberation Struggle: A case study of the United Democratic Front, 1983-1987. Aldershot: Ashgate Publishers.

Joll, J. 1979. The Anarchists. London: Methuen.

Karis,T. \& Carter, G. (Eds). 1973. From protest to challenge: A documentary history of African politics in South Africa 1882-1964 (Volume 3). Stanford, California: Hoover Institution Press.

Kgosana, P.A. 1988. Lest we Forget: An Autobiography. Johannesburg: Skotaville Publishers.

Leatt, J., T. Kneifel \& K. Nurnberger. (Eds.) 1986. Contending Ideologies in South Africa. Cape Town: David Philip Publishers.

Lermontov, M. 1984. A Hero of Our Time. Oxford: Oxford University Press.

Louw, C. (Samesteller). Op reis na die ANC. Kaapstad: Voorbrand Publikasies.

Mangena, M. 1989. On your own: Evolution of Black Consciousness in South Africa/Azania. Braamfontein: Skotaville Publishers.

Maree, J. (Ed.) 1987. The Independent Trade Unions 1974 - 1984: Ten Years of the South African Labour Bulletin. Johannesburg: Ravan Press.

Meli, Francis. 1990. A history of the ANC: South Africa belongs to us. Harare: Zimbabwe Publishing House. 
Naude, C-P. 1999. Hearing spirit engines. Unpublished film script (Working copy). Yeoville, South Africa.

Ntloedibe, E.L. 1995. Here is a Tree: Political Biography of Robert Mangaliso Sobukwe. Mogoditshane (Botswana): Century-Turn Publications.

Omar, I. 1988. Reform in Crisis: Why the Tricameral Parliamentary System has failed. Johannesburg: Jonathan Ball Publishers.

O'Meara, D. 1983. Volkskapitalisme. Class, Capital and Ideology in the Development of Afrikaner Nationalism, 1934 - 1948. Johannesburg: Ravan Press.

Orie, T. 1993. Raymond Mhlaba and the genesis of the Congress Alliance: A political biography. MA Dissertation (Unpublished). University of Cape Town (UCT).

Price, R.M. \& C.G. Rosberg (Eds.) (date unknown) The Apartheid Regime: Political Power and Racial Domination. Cape Town: David Philip Publishers.

Prior, A. 1983-4. "South African Exile Politics. A Case Study of the African National Congress and the South African Communist Party", Journal of Contemporary African Studies 3(1/2): 181-196.

Slabbert, F. van Zyl, 1985. The Last White Parliament, Jonathan Ball, Johannesburg.

Slabbert, F van Zyl. 1992. South Africa in Transition: The Quest for Democracy. London: Penguin Forum Series.

Solomon, H. \& Liebenberg, I. 2000. Consolidation of Democracy in Africa-A view from the South. Aldershot: Ashgate Publishers.

Strydom, H. \& I. Wilkens. 1978. The Super Afrikaners: Inside the Afrikaner Broederbond. Johannesburg: Jonathan Ball Publishers.

Van der Westhuizen, G. (1994). The South African Congress of Democrats. In: Liebenberg, I et al: $72-80$.

Van der Westhuizen, G. (1994) The Liberal Party of South Africa, 1953-1968. In: Liebenberg, I et al: $81-91$.

Van Staden, G. 1988. "Return of the Prodigal Son: Prospects for a Revival of the Pan Africanist Congress", International Affairs Bulletin 12(3): 32 -43.

Van Vuuren, W. 1985. "Domination through Reform: The Functional Adaptation of Legitimizing Strategies", Politikon 12(2): 47-58.

Villa-Vicencio, C. 1988. Trapped in Apartheid: A Socio-theological History of the English-speaking Churches. New York: Orbis Books.

Walker, E. 1928. The Inner History of the National Convention of South Africa. Pretoria/Cape Town: T. Maskew Miller Publishers. 